\title{
Improvement of the Efficiency of the Recruitment Policy of the Medical Care as a Factor in the Reduction of the Staff Shortage of the Industry
}

\author{
Eleanor Chernenko \\ Department of State and Municipal Management \\ FSBI of HE Kuban State Technological University \\ Krasnodar, Russia \\ 79184814276@yandex.ru
}

Nadezhda Klimovskikh

Kuban State Agrarian University

Department

Nadin180676@yandex.ru

\author{
Inna Lebedeva \\ Community Health, Healthcare and History of Medicine \\ Department \\ Kuban State Medical University \\ Krasnodar, Russia \\ kinnas@mail.ru
}

Elena Gorlova

Department of State and Municipal Management FSBI of HE Kuban State Technological University

Krasnodar, Russia

elenagorlova1004@gmail.com

\begin{abstract}
A staff shortage has a negative impact on the functioning of both an individual service or enterprise (organization, institution) in general, and the entire industry in which it arises. This problem is observed most acutely today in the social sphere, in particular, for education and health care, which are strategic sectors of existence of any state. In this regard, the article explores the problem of the staff shortage in the health care sector of the Krasnodar Territory. The analysis has shown that in the Krasnodar Territory a staffing level of a health care personnel is on average $75 \%$, but, as in the whole country, it is significantly higher in medical organizations providing an inpatient care than in an outpatient service. The key problems of the staff shortage are: low wages of young professionals, a long training period for the professionals, poor material and technical base of medical institutions, etc. The staff shortage primary negatively affects the efficiency and quality of medical service. To maintain positive trends and completely eliminate the staff shortage, medical universities need to increase not only the number of trained graduate-therapists, but also narrow professionals, who will come to work in outpatientpolyclinic organizations. An analysis of the structure of terminated agreements under the "Zemsky Doctor" Program has revealed an inefficiency of the regional recruitment policy in the medical care in 8 municipalities of the Krasnodar Territory. In these conditions, the importance of social-psychological methods of motivation arises. A special place is occupied by a material stimulation, which is not only economic, but also socialpsychological in nature. Under these conditions, great attention should be paid to an application of the two-factor theory of the motivation by $F$. Herzberg in the health care system, focusing on hygienic factors
\end{abstract}

Keywords: staff, recruitment policy, staff shortage, "Zemsky Doctor", motivation

\section{INTRODUCTION}

In modern society, professional activity, especially associated with an increased level of responsibility to the citizen and society, requires the representatives of the social sphere to constantly improve their professional skills.

At the same time, changes in the social and economic spheres of the society, the requirements for professionals both by an employer and a service consumer dictate the necessity for creating a dynamic system of additional professional education based on the principle of the continuing education, attracting leading industry experts to the training, as well as using simulation training and distance learning technologies.

The effectiveness of the health care system largely determines the state of the staff potential of the industry, its quantitative and qualitative characteristics, such as number, structure, level of professional training, work motivation, and health condition of medical workers.

\section{MethodS AND RESUltS}

The basis of the study is the integrated reporting form of state statistical observation No. 30 "Information about the medical organization" for medical organizations of the Krasnodar Territory for 2018. Staffing level indicators have been calculated, incl. the coefficient of a secondary 
employment of the doctors in the medical network as a whole and in medical organizations providing outpatient and inpatient care, separately.

The article uses statistical and analytical research methods.

\section{DISCUSSION}

Health workforce plays a key role in organizing and delivering care in all countries. The ability of health systems to function effectively is largely dependent on the availability of a sufficient number of skilled health workers working in conditions that promote their motivation and involvement. At the global and regional level, a number of measures have already been taken to address human resources for health: the "Global Strategy for the Development of Human Resources for Health: Human Resources 2030" has been approved and the United Nations High-level Commission on Employment in Health and Economic Growth has been established. [1,2]

The Thirteenth General Program of Work of the World Health Organization (WHO) 2019-2023. It is noted that the provision of safe and high-quality services depends on the availability of qualified health personnel and social assistance that are appropriate for their purpose and distributed equitably. [3]

In September 2017, the WHO Regional Committee for Europe approved resolution EUR/RC67/R5, which calls on Member States to step up their efforts to ensure sustainable human resources for health in order to transform education and training, as well as optimize efficiency, quality and effectiveness health personnel work. For this, it is necessary to invest in human resources for health care in volumes that meet the needs not only at the current moment, but also focusing on the strategic development of the industry. [4]

There is an acute question of a shortage of medical staff in Russia - the shortage of the middle medical staff is more than 250 thousand people, doctors - more than 40 thousand; annually about $10 \%$ of doctors leave the industry and only $2 \%$ because of a retirement, and the rest because of working conditions and disappointed expectations from the profession.

According to the Ministry of Health, only outpatient clinics are deficient in more than 25 thousand doctors and about 130 thousand middle medical staff. Throughout the country, there are acute shortages of oncologists, psychiatrists, orthopedists, ophthalmologists, neurologists and other doctors, however, only 1 thousand job applicants are registered at the labor market. The actual need for health professionals to fill vacancies is many times greater. [5, 6]

According to estimates by the professor of the Department of Management and Health Economics of the NRU HSE I.M. Sheiman, the norm of the citizens attached to a therapist in a polyclinic is exceeded two - three times, 2.66 thousand people per a therapist, but there are regions where this indicator is even higher: Irkutsk region - 3.9 thousand, Sverdlovsk - 4.6 thousand, Kurgan region - 4.98 thousand people. [7]

The shortage of ophthalmologists in the regions is 240 people; in polyclinics, the deficit of trauma orthopedists is more than 600 professionals with a surplus in hospitals.
Psychiatrists (a total deficit of 1059 people) are not enough in polyclinics and in hospitals. In total, about 4 thousand oncologists are lacking in the country, while in some regions oncology health centers are $100 \%$ staffed. [1]

As an attempt to eliminate staff shortages, the possibility of attracting foreign professionals from among former compatriots with the appropriate qualifications is being considered. In early October, the Ministry of Labor and Social Protection of the Russian Federation put up for public discussion a draft order on the list of professions whose proprietors will be given a simplified procedure for obtaining Russian citizenship. At the request of the regional authorities, the list was supplemented by doctors and paramedics. $[1,8,9]$.

\section{CONCLUSIONS}

In the Krasnodar Territory, there is also a shortage of medical workers, as of 1 January 2018, more than 7 thousand doctors and more than 9 thousand middle medical staff are not enough in the region. [10]

As of 01.01.2018, 11889 people are working in the municipal medical organization of the city of Krasnodar, including: doctors of all specialties - 3244 people, middle medical staff - 5007 people, junior medical staff - 1660 people. As of 01.01 .2018 , the staffing level of medical personnel is $75.6 \%$ for all grades, including: for medical posts - $76.9 \%$, for middle medical staff - $74.4 \%$, and for junior medical staff - 70.1\%. [11]

As of 1 January 2019, the staffing level of the medical personnel in medical organizations of the Krasnodar Territory as a whole amounted to $77.5 \%$, including $76.6 \%$ in organizations providing outpatient care, and $82.0 \%$ - inpatient care. In this case, the coefficient of secondary employment (CSE) was 1.23.

At that, in the region there is no significant shortage of narrow professionals, which is characteristic of the country as a whole. Thus, the staffing level of neurologists is $83.8 \%$ (81.6\% in polyclinics and $86.8 \%$ in hospitals, CSE 1.17); oncologists - $81.9 \%(77.2 \%$ in polyclinics and $88.7 \%$ in hospitals, CSE 1.2); psychiatrists - $78.2 \% \quad(76.7 \%$ in polyclinics and $80.0 \%$ in hospitals, CSE 1.34); ophthalmologists $77.9 \%$ (78.3\% in polyclinics and $84.3 \%$ in hospitals, CSE 1.02); trauma orthopedists - $84.0 \%$ (78.9\% in polyclinics and $88.0 \%$ in hospitals, CSE 1.29).

Today, medical education institutions graduate about 100 thousand young professionals with higher and secondary professional education a year. Annually about 500 thousand people undergo training in the system of continuing professional education. The system of admission to higher education institutions on the basis of contracts on employersponsored education is being developed and the technology of the educational process is being improved. The contract system for employing young professionals is becoming more widespread. [6, 12]

In order to reduce staff shortages in the Krasnodar Territory, the programs "Medical staff for rural health care" and "Zemsky doctor" are being implemented, targeted 
highly qualified staff (residency programs) and additional professional education in professional retraining programs in the specializations of "cardiology", "neurology", "general medical practice (family medicine)", "oncology "," pediatrics "," therapy ". [14]

On 1 January, 2016, the Federal Law No. 389-FZ of 29 December 2015 "On Introduction of Amendments to Certain Legislative Acts of the Russian Federation" came into force, according to which the right to carry out medical or pharmaceutical activities on the territory of the Russian Federation based on a certificate of specialist prolonged until 1 January, 2026.

By the order of the Ministry of Health of Russia dated 21 November, 2017 N 926. The Concept for the Development of Continuing Medical and Pharmaceutical Education in the Russian Federation for the period until 2021 was approved. The concept is a system of views on the content, principles and main priorities of the state policy aimed at ensuring medical and pharmaceutical workers to improve their professional knowledge and skills throughout their lives, as well as constantly improving their professional level and expanding their qualifications.

Mentioned measures made it possible to create conditions for the modernization of the system of additional professional education, based on the principle of the continuing education throughout the professional activities of a professional. However, from the point of view of the public administration system, serious shortcomings were revealed. The main one is that the cancellation of the internship deprived medical graduates of the opportunity to gain practical experience in hospitals.

Previously, after studying for six years, graduates of a medical university usually went to an internship. Under the guidance of experienced doctors, they received practical skills, got acquainted with work in different departments and a year later, having received a certificate of a specialist, they could already independently treat patients. The increase in the volume of a practical training, and the formation of a system for assessing the knowledge of graduates, reduced to a common standard (in the form of the accreditation) reduced the need for an intermediate element in the form of the internship. Since 2017, the internship in Russia has been canceled. Now graduates are offered to immediately go to work in the polyclinic. $[3,6,17]$

Moreover, the motivation of professionals for a systematic training is achieved due to the fact that the learning results will be in demand in the student's practical activities. The system provides the possibility of a discrete training through the gradual development of individual training courses, subjects, disciplines, modules, practical skills. In addition, the training provides the opportunity for an interactive contact of a professional with educational, scientific, medical organizations and colleagues, which includes a participation in professional seminars, conferences, a private research, writing scientific (research) works, reading periodicals, an information search, an internship, teaching, consulting, examination, mentoring, and the electivity of an educational process a vocational secondary education in a number of medical specializations; since 2019 - people who have completed higher education in educational programs for the training of graduates of the pharmaceutical and dental faculties passed the accreditation. Since 2017, graduates of the medical and pediatric faculties, professionals in medical and precautionary care, medical biophysics, medical biochemistry, medical cybernetics have been granted an access to work through the 
- nurses of pediatricians and general practitioners of local service, as well as nurses of general family practitioners - 21268.0 rubles;

- paramedics and nurses of the emergency medical care 30018.0 rubles.

The average salary of the junior medical staff is at the level of 16350.0 rubles.

The average salary for 12 months of 2017 compared to 2016 increased in the category:

- medical staff - by $5.8 \%$;

- middle medical staff - by $1.1 \%$;

- junior medical staff - by $3.8 \%$. [21]

One of the main reasons for the low staffing level and the lack of medical staff is the insufficiently high level of remuneration in the healthcare system in comparison with a number of other sectors of the economy. Moreover, even its increase does not always allow to motivate medical staff to increase labor productivity, due to the already existing work overload.

A revision of the Russian Ministry of Health in connection with the mass dismissal of surgeons in Nizhniy Tagil (Central city hospital No. 1) showed the inefficiency of the regional recruitment policy in the healthcare. Moreover, subsequent dismissals in Chelyabinsk, the Kurgan region (Kurgan tuberculosis health center) and statements of readiness to resign in Perm (City hospital No. 6) and the Moscow Region (National medical research center for oncology named after Blokhin) indicate the absence of actual monitoring of a movement of medical staff, taking into account medical loads, wages, necessity for professionals and long-term plans for their preparation throughout the country as a whole.

Despite the fact that in many constituent entities of the Russian Federation there are medical faculties at universities or even individual medical universities, the regions are poorly provided with the medical staff. Frequently, regional ministries of health do not formulate applications for years to the Russian Ministry of Health to finance residency statefunded places. In addition, the head doctors of the region do not receive proper training in the basis of management, which negatively affects the quality of administration. [22]

The accumulated problems in work collectives are not being resolved, medical workers are not heard, and this translates into appeals to the President of the Russian Federation. In all cases, common problems are identified: staff shortages, high workloads, low wages. [23, 24]

The outflow of staff from the medical industry is also noted in the Krasnodar Territory, while this has more affected therapists and general practitioners in rural areas. In the Krasnodar Territory for 2012 - 2017, for various reasons, young doctors terminated 225 contracts. The largest number of terminated contracts at the initiative of the employee occurred in 8 municipalities (Figure 1).

The average salary of the middle medical staff is at the level of 22445.0 rubles, including: 


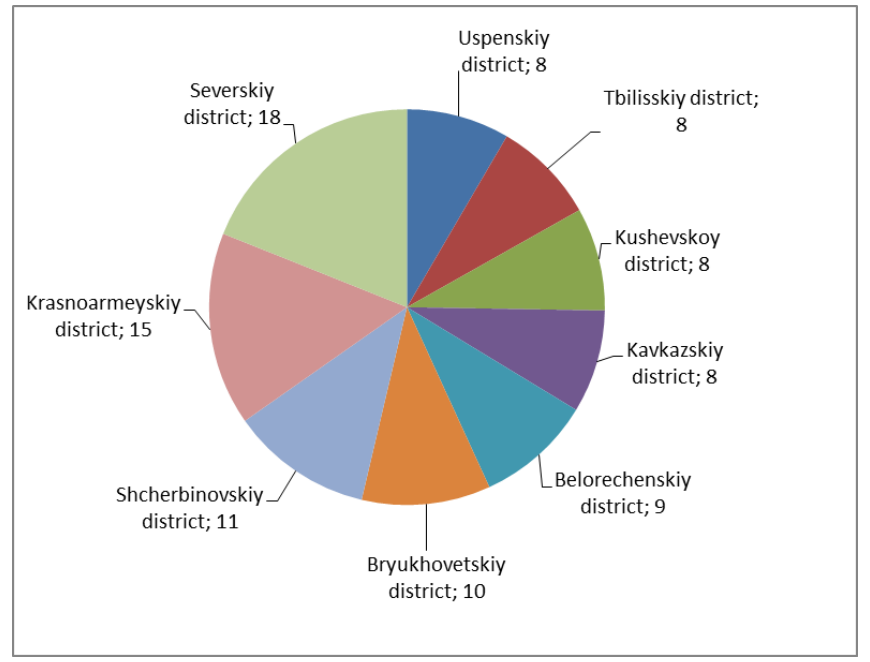

Fig. 1. The structure of terminated contracts by regions of the Krasnodar Territory

Most young professionals terminate agreements with medical institutions due to the working conditions created in them.

Work motivation is the process of influencing individual components or the installation system as a whole in order to stimulate the employee to work effectively, in accordance with the plan for achieving the organization's goals. The theories of motivation that exist today can be divided into two groups: substantive and procedural.

Substantive theories are based on an analysis of human needs, which force people to act in a certain way. The main focus is on determining the list and structure of people's needs (works by A. Maslow, F. Herzberg and D. MacClelland). The basis of procedural theories of motivation is the study of cognitive characteristics of the perception and interpretation of information and cognition of people (works by V. Wroom, Porter-Lawler, MacGregor). [25]

Herzberg's theory of motivation, which distinguishes two groups of factors different in nature, is of practical interest for healthcare administration. The first includes motivating factors associated with the nature and essence of work activity itself: career growth; recognition of credits; payment related to labor results; high degree of responsibility. And the second keeping at work, forming the working environment (hygienic factors): working conditions (a convenient work schedule, sanitary and hygienic conditions, a comfortable workplace, lack of unnecessary stress); the amount of earnings and the availability of material benefits; interpersonal relationships with administrators, colleagues and subordinates. [26, 27]

As shown in the presented data, the hygienic factors are decisive for doctors. The increase in earnings itself, as a motivating factor, does not contribute to the retention of a professional in a workplace if issues of high workload, shifts, work schedule, team relationships, stressful situations remain unresolved. The latter, including the not always adequate reaction of patients, is increasingly found, especially in the work of emergency medical service teams. [28]
Taking into account the urgency of the problem of the staff shortage in the municipality of the Krasnodar city, events will be actively implemented to improve skills and professional retraining, the development of targeted training, training in postgraduate vocational education programs with subsequent employment of graduates, Also there should be the increase of the staffing level in a village due to compensation payments on the expenses for rental payments, heating and lighting to employees of municipal institutions of the health care who live and work in rural areas.

The total amount of funding needed to implement the activities of the subprogram "Staff support of the healthcare system" of the municipal program of the municipality of Krasnodar "Development of the healthcare in the municipality of Krasnodar is 122502.8 thousand rubles. Time frame for implementation: 2015 - 2020

Target indicators of the subprogram: Provision of the doctors, Provision of the middle medical staff, Percentage of the plan for professional training (retraining) of medical staff per a year, Proportion of students receiving a scholarship, Staffing level of health facilities operating in rural areas of the municipality of Krasnodar

Together, the solution of these problems will improve the quality of training of medical and pharmaceutical professionals, reduce the level of shortage of the medical staff and, as a result, improve the quality of the medical care provided to dwellers of the municipality of Krasnodar. [23]

The implementation of these tasks will contribute to the social and economic and cultural development of the Russian Federation.

\section{REFERENCES}

[1] Global strategy on human resources for health: workforce 2030 / WHO, 2019, p. 64.

[2] A.G. Saharov, "Perspektivy realizacii Celej ustojchivogo razvitiya OON v Rossii," Vestnik mezhdunarodnyh organizacij, vol. 14(1), 2019, pp. 189-206.

[3] World Health Assembly, 71. (2018). Thirteenth General Programme of Work, 2019-2023 / World Health Organization. - 1p. - URL: https://extranet.who.int/iris/restricted/handle/10665/279451].

[4] Towards a sustainable health workforce in the WHO European Region: framework for action / Regional Committee for Europe. - Resolution EUR/RC67/R5. - Budapest, Hungary, 11-14 September 2017, p. 4].

[5] Ne mestnyj anamnez: migranty pomogut reshit' kadrovyj vopros v medicine [Elektronnyj resurs] / E. Sidorenko - Setevoe izdanie IZ.RU 10.10.2019. - Rezhim dostupa: https://iz.ru/928434/elena-sidorenko/nemestnyi-anamnez-migranty-pomogut-reshit-kadrovyi-vopros-vmeditcine]

[6] N.G. Korshever, "Intersectoral coperation in the sphere of public health care: ways of optimization," Russian open medical jornal, vol. 6(3), 2017, p. 308.

[7] Kogo ty lechish': molodyh vrachej dopuskayut tol'ko v polikliniki [Elektronnyj resurs] / M. Rubnikovich - Setevoe izdanie IZ.RU 01.09.2019. - Rezhim dostupa: https://iz.ru/914834/mariiarubnikovich/kogo-ty-lechish-molodykh-vrachei-dopuskaiut-tolko-vpolikliniki].

[8] M.M. Akulich, "Russkoyazychnye ekspaty v stranah Blizhnego Vostoka," Vestnik Rossijskogo universiteta druzhby narodov. Seriya: Sociologiya, vol. 19(4), 2019, pp. 756-768. 
[19] A.S. Fedonnikov, "Communication with patients and colleagues in rehabilitation process: needs, expectations and responsibility of the orthopedic surgeons," Russian Open Medical Journal, vol. 8(3), 2019, p. 306. regionah Rossii: opyt strukturnogo modelirovaniya ustanovok naseleniya," Vestnik Rossijskogo universiteta druzhby narodov. Seriya: Sociologiya, vol. 19(4), 2019, pp.737-755.

[10] Postanovlenie Zakonodatel'nogo Sobraniya Krasnodarskogo kraya ot 20.06.2018 №509-P «O soglasovanii predlozheniya o vnesenii izmenenij $\mathrm{v}$ gosudarstvennuyu programmu Krasnodarskogo kraya «Razvitie zdravoohraneniya»]

[11] Postanovlenie Administratsii munitsipal'nogo obrazovaniya gorod Krasnodar ot 17 okt’abr’a 2014 goda №7612 “Ob utverzhdenii munitsipal'noy programmy munitsipal'nogo obrazovaniya gorod Krasnodar "Razvitie zdravookhraneniya v munitsipal'nom obrazovanii gorod Krasnodar"'’]

[12] "Osnovy kadrovoy politiki v zdravookhranenii Rossiyskoy Federatsii," Glavnyy vrach, vol.7, 2012, pp. 7-12.

[13] Edinorossy obsudili kadrovoe obespechenie medicinskoj sfery [Elektronnyj resurs] / Zakonodatel'noe Sobranie Krasnodarskogo kraya - 20.06.2018. - Rezhim dostupa: http://www.kubzsk.ru/news/2140/]

[14] H. Hazrati, V.Z. Gavgani, M. Ghojazadeh, L. Vahedi, "Problem-based learning in dentistry and interfiled comparison: a citation analysis study," Russian Open Medical Journal, vol. 5(3), 2016, p. 301.

[15] T. Sharifi, "The relationship between individual identities and the mental health among students," Russian Open Medical Journal, vol. 4(3), 2015, p. 301.

[16] L. Khanal, S. Shah, S. Koirala, "Exploration of preferred learning styles in medical education using vark modal," Russian Open Medical Journal, vol. 3(3), 2014, p. 305.

[17] Yu.R. Vishnevskij, "Paradoksy modernizacii vysshego obrazovaniya: itogi 20-letnego monitoringa v Sverdlovskoj oblasti," Vestnik Rossijskogo universiteta druzhby narodov. Seriya: Sociologiya, vol. 19(2), 2019, pp. 289-301.

[18] Zh.V. Puzanova, "Social'noe izmerenie studencheskih problem v kontekste razvitiya infrastruktury sovremennogo universiteta," Vestnik Rossijskogo universiteta druzhby narodov. Seriya: Sociologiya, vol. 19(4), 2019, 800-813.

[20] Rabochaya vstrecha s Predsedatelem Pravitel'stva Dmitriem Medvedevym 09.10.2019 [Elektronnyj resurs] / Oficial'nyj sajt Prezidenta Rossii $\quad-\quad$ Rezhim dostupa: http://www.kremlin.ru/events/president/news/copy/61759].

[21] Postanovlenie Administratsii munitsipal'nogo obrazovaniya gorod Krasnodar ot 17 okt'abr’a 2014 goda №7612 “Ob utverzhdenii munitsipal'noy programmy munitsipal'nogo obrazovaniya gorod Krasnodar "Razvitie zdravookhraneniya v munitsipal'nom obrazovanii gorod Krasnodar"'’].

[22] Proverka situacii s uvol'neniem tagil'skih hirurgov vyyavila otsutstvie raboty s medkadrami [Elektronnyj resurs] / TASS - 12.09.2019. Rezhim dostupa: https://tass.ru/obschestvo/6877243].

[23] Proverka situacii s uvol'neniem tagil'skih hirurgov vyyavila otsutstvie raboty s medkadrami [Elektronnyj resurs] / TASS - 12.09.2019. Rezhim dostupa: https://tass.ru/obschestvo/6877243].

[24] T.A. Hagurov, "Dinamika mirovozzrencheskih ustanovok molodezhi Kubani," Vestnik Rossijskogo universiteta druzhby narodov. Seriya: Sociologiya, vol. 3, 2019, pp. 470-480.

[25] I.F. Devyatko, "Razrabotka podhoda k kolichestvennoj mul'timodal'noj ocenke kognitivnoj nagruzki interv'yuerov: rezul'taty pilotnogo kvazieksperimenta," Vestnik Rossijskogo universiteta druzhby narodov. Seriya: Sociologiya, vol. 18(4), 2018, pp. 627-637.

[26] M.A. Tatarnikov, "Trudovaya motivatsiya rabotnikov medetsinskikh organizatsiy," Glavnyy vrach, vol. 8, 2018, pp.3-8.

[27] V.A. Cvyk, "Nravstvennye cennosti professional'noj deyatel'nosti v informacionnom obshchestve," Vestnik Rossijskogo universiteta druzhby narodov. Seriya: Sociologiya, vol. 19(3), 2019, pp. 530-542.

[28] M.V. Kiseleva, "Investigation of emotional burnout in bank employees working in "person-to-person" system," Russian Open Medical Journal, vol. 7(3), 2018, p. 307. 